\title{
Alzheimer's disease, dementia, and stem cell therapy
}

\author{
Thomas Duncan and Michael Valenzuela*
}

\begin{abstract}
Alzheimer's disease (AD) represents arguably the most significant social, economic, and medical crisis of our time. Characterized by progressive neurodegenerative pathology, AD is first and foremost a condition of neuronal and synaptic loss. Repopulation and regeneration of depleted neuronal circuitry by exogenous stem cells is therefore a rational therapeutic strategy. This review will focus on recent advances in stem cell therapies utilizing animal models of $A D$, as well as detailing the human clinical trials of stem cell therapies for $A D$ that are currently undergoing development.

Keywords: Alzheimer's disease, Embryonic stem cells, Induced pluripotent stem cells, Mesenchymal stem cells, Neural stem cells
\end{abstract}

\section{Background}

Approximately 50 million people live with dementia, with the estimated global cost of care being US $\$ 818$ billion. As age is the predominant risk factor and national demographics are rapidly ageing, this figure is set to rise to 132 million people by 2050 [1]. Dementia is a fatal clinical disorder characterised by amnesia, progressive cognitive impairment, disorientation, behavioural disturbance, and loss of daily function; Alzheimer's disease (AD) is the most common associated pathology. It can be argued that dementia is one of the most significant social, economic, and medical challenges of our time.

Less than $5 \%$ of $\mathrm{AD}$ cases are familial, caused by highly penetrant autosomal mutations of the PSEN1, PSEN2, and, less frequently, APP genes. The majority of $\mathrm{AD}$ cases are late onset and sporadic, with established risk factors beyond age including cardiovascular disease, low education, depression, and the

* Correspondence: michael.valenzuela@sydney.edu.au

Regenerative Neuroscience Group, Brain and Mind Centre \& Sydney Medical School, University of Sydney, Sydney, NSW 2050, Australia
apolipoprotein-E4 (ApoE4) gene. Sporadic AD is accordingly of multifactorial origins, driven in part by a complex genetic profile and in part by interacting and intersecting environmental exposures.

It should therefore not be surprising that $\mathrm{AD}$ pathology is diverse. Four core features can be discerned. Firstly, tau, an intracellular microtubule-associated protein within neurons important for structural support and axonal transport, becomes hyperphosphorylated, leading to microtubule collapse and aggregation into neurofibrillary tangles. Secondly, sequential cleavage of the APP protein by $\beta$ - and $\gamma$-secretase enzymes leads to extracellular accumulation and aggregation of beta amyloid $(A \beta)$ protein fragments, visible as amyloid plaques in the AD brain. Many pharmacological approaches have attempted to promote amyloid clearance by vaccination [2] and decrease production via secretase inhibition [3]. However, results from human clinical trials indicate that amyloid pathology does not correlate with clinical symptoms and therefore may not be a therapeutically relevant target. The third core feature of $\mathrm{AD}$ is the presence of activated microglia, the resident macrophages of the central nervous system (CNS), and found in close association with amyloid plaques. Present from the early stages of the disease, their numbers then decline in the advanced AD brain. Activated microglia produce cytokines, such as tumour necrosis factor (TNF)- $\alpha$, interleukin (IL) $-1 \beta$, and nitric oxide (NO), that may exacerbate or attenuate neuroinflammation [4]. Mass neuronal and synaptic loss represents the forth core feature of $\mathrm{AD}$ and is the closest correlate of cognitive decline in early $\mathrm{AD}$ [5]. AD-related neurodegeneration in the temporal lobe follows a distinct pattern. The entorhinal cortex is first affected, then progressing to the subiculum and CA1 hippocampal subregion and basal forebrain networks. Atrophy of these brain regions and the hippocampus overall co-vary with verbal episodic memory deficits in $\mathrm{AD}$ patients [5]. In later 
stages of the disease neurodegeneration spreads throughout the temporal lobes, eventually affecting most cortical layers. The precise temporal sequencing of this complex admixture of pathologies in human sporadic $A D$ is the subject of intense debate.

Due to the progressive nature of $\mathrm{AD}$, if a stem cell therapy is to be successful it must target a welldefined clinical subset of patients. Given the involvement of hippocampal circuitry in the early phases of the disease, we suggest this region as a potential therapeutic target. There is now an enormous global demand for new effective therapies that not only halt progression but also reverse symptoms. In this review, we argue that a potentially effective strategy is to target the biological feature most closely tied to symptoms, namely neurosynaptic loss. Specifically, we focus on recent advances in cell-based therapies that aim at repopulation or regeneration of degenerating neuronal networks in AD.

\section{Stem cell classes}

An important step in developing any stem cell therapy is to choose the appropriate cell source. The most commonly utilized cells in recent $\mathrm{AD}$ studies are embryonic stem cells (ESCs), mesenchymal stem cells (MSCs), brain-derived neural stem cells (NSCs), and induced pluripotent stem cells (iPSCs). ESCs are derived from the inner cell mass of the developing blastocyst (at embryonic day 5 to 6) and are classified as pluripotent because they possess the ability to generate cell types from the ectodermal, mesodermal, and endodermal germ layers. MSCs are involved in the development of mesenchymal tissue types and can be harvested from umbilical cord blood (UCB-MSCs) or Wharton's jelly, and also remain present in several adult stem cell niches including bone marrow and adipose tissue. Classified as multipotent, MSCs are able to generate multiple cell types that share a common embryonic origin, namely the mesodermal germ layer. Despite this, phenotypic expression and the differentiation potential of MSCs can vary according to the tissue of origin [6]. Similarly multipotent, NSCs are responsible for the generation of all neural cell types during development. While also present in the adult brain, they are restricted to the discrete neurogenic niches of the subventricular zone and the granular layer of the dentate gyrus in the hippocampus. Finally, iPSCs are derived from mature somatic cells in vitro, commonly adult dermal fibroblasts, and are genetically modified by small molecule treatment or viral vector-delivered transcription factor upregulation to become pluripotent and ESC-like in phenotype and differentiation capacity [7].

\section{Endogenous repair}

There are several theoretical approaches to the design of a stem cell therapeutic strategy for early AD. One is to target upregulation of resident NSC niches within the adult brain, in effect stimulating adult hippocampal neurogenesis to compensate for neurodegeneration. Adult hippocampal neurogenesis may have a key role in learning and memory, and so promoting this process may help counter the amnestic symptoms of early AD. One option has been to upregulate (pharmacologically or with gene therapy) those growth factors known to positively regulate neurogenesis, including brain-derived neurotrophic factor (BDNF), insulin growth factor-1 (IGF-1), nerve growth factor (NGF), and vascular endothelial growth factor (VEGF) [8].

This approach is, however, complicated by several quantitative challenges. Firstly, the rate of hippocampal neurogenesis decreases with age in humans, with an estimated 800 new neurons produced daily in adulthood declining to $\sim 100$ in late life under disease-free conditions. Since the best estimates suggest neuronal number is stable in normal ageing, this is therefore the minimum required to achieve neuronal equilibrium because of rapid neuronal turnover. Secondly, in AD there is mass loss of hippocampal neurons. In the dentate gyrus the loss is estimated at $\sim 1 \mathrm{M}$, and in CA1 the loss is estimated at $\sim 5$ million. Hence, to compensate for AD there would need to be an order-fold increase in hippocampal neurogenesis to normalise dentate gyrus numbers. Furthermore, adult hippocampal neurogenesis has no effect whatsoever on CA1 neurons and so the main neuronal deficit in early AD is unaddressed. Third, this approach must account for the effect of AD pathology on neurogenesis, for which there is conflicting evidence from animal studies $[9,10]$. Overall, endogenous strategies for neuronal repair in early $\mathrm{AD}$ lack potency and miss one of the main neuronal targets.

\section{Exogenous cell therapy}

Exogenous cell therapies aim to restore degenerate neuronal networks, and consequently cognitive function, through the introduction of stem cells. These stem cells may be used as a cellular delivery system, utilizing a paracrine "bystander" mechanism through either native or induced production of neuroprotective growth factors. Alternatively, therapeutic restoration may occur through differentiation and participation of the stem cells in repopulating degenerate neuronal circuits. This is a finely balanced, complex, and multistep process. Each class of stem cells has different propensities to achieve these approaches, as briefly reviewed here. Details of recent AD model stem cell transplantation studies featured in this review are summarized in Table 1. 
Table 1 AD rodent model stem cell transplantation studies in the last 5 years

\begin{tabular}{|c|c|c|c|c|c|c|}
\hline Study & [23] & [24] & [26] & [27] & [34] & [35] \\
\hline Cell type & $\begin{array}{l}\text { Murine embryonic } \\
\text { NSCs }\end{array}$ & Human fetal NSCs & Human fetal NSCs & Human fetal NSCs & Human UCB-MSCs & Human PD-MSCs \\
\hline Model & $\begin{array}{l}\text { B6C3-Tg } \\
\text { (APPswe/PSEN1dE9) } \\
\text { transgenic mice }\end{array}$ & $\begin{array}{l}\text { NSE-APPswe } \\
\text { transgenic mice }\end{array}$ & $\begin{array}{l}\text { Tg2576 } \\
\text { (APPswe) transgenic } \\
\text { mice }\end{array}$ & $\begin{array}{l}3 \times T_{g}-\mathrm{AD} \\
\text { transgenic mice } \\
\text { CaM/Tet-DT } \mathrm{A} \text { mice }\end{array}$ & $\begin{array}{l}\text { APP/PS1 transgenic } \\
\text { mice }\end{array}$ & $\begin{array}{l}\mathrm{A} \beta_{1-42} \\
\text { cerebrally infused } \\
\text { mice }\end{array}$ \\
\hline $\begin{array}{l}\text { Delivery } \\
\text { route }\end{array}$ & $\begin{array}{l}\text { Bilateral intra- } \\
\text { hippocampal } \\
\text { stereotactic injection } \\
5 \times 10^{5} \text { to } 1 \times 10^{6} \\
\text { cells Sham: PBS } \\
\text { vehicle }\end{array}$ & $\begin{array}{l}\text { Bilateral intra- } \\
\text { ventricular } \\
\text { stereotactic injection } \\
5 \times 10^{5} \text { cells Sham: } \\
\mathrm{H}-\mathrm{H} \text { buffer vehicle }\end{array}$ & $\begin{array}{l}\text { Bilateral intra- } \\
\text { hippocampal } \\
\text { stereotactic injection } \\
2.5 \times 10^{5} \text { cells Sham: } \\
\text { culture media } \\
\text { vehicle }\end{array}$ & $\begin{array}{l}\text { Bilateral intra- } \\
\text { hippocampal } \\
\text { stereotactic injection } \\
1 \times 10^{5} \text { cells Sham: } \\
\text { vehicle }\end{array}$ & $\begin{array}{l}\text { Three bilateral } \\
\text { intra-hippocampal } \\
\text { injections at } 2 \text { week } \\
\text { intervals } \\
1 \times 10^{5} \text { cells per } \\
\text { injection Sham: PBS } \\
\text { vehicle }\end{array}$ & $\begin{array}{l}\text { Intravenous injection } \\
1 \times 10^{5}, 5 \times 10^{5} \text {, or } \\
1 \times 10^{6} \text { cells Sham: } \\
\text { Saline vehicle }\end{array}$ \\
\hline Findings & $\begin{array}{l}10 \text { weeks } \\
\text { post-operation } \\
\text { Extensive donor cell } \\
\text { migration } \\
14.6 \% \text { neuron, } 36.2 \% \\
\text { astrocyte, and } 28.5 \% \\
\text { oligodendroctye } \\
\text { phenotypic } \\
\text { differentiation } \\
\text { Improved spatial } \\
\text { memory (Morris } \\
\text { water maze) } \\
\text { Decreased } \\
\text { expression of } \\
\text { pro-inflammatory } \\
\text { cytokines IL-1 } \beta, \text { IL-6, } \\
\text { TNF-a and PGE2 } \\
\text { A levels } \\
\text { unchanged }\end{array}$ & $\begin{array}{l}7 \text { weeks } \\
\text { post- operation } \\
\text { Extensive donor } \\
\text { cellular migration } \\
\text { NSC phenotype } \\
\text { remained in >80\% } \\
\text { of cells } \\
\text { Improved spatial } \\
\text { memory (Morris } \\
\text { water maze) } \\
\text { Decreased levels of } \\
\text { phosphorylated tau, } \\
\text { A } \text { plaques, } \\
\text { astrogliosis, } \\
\text { microgliosis and } \\
\text { apoptosis } \\
\text { Decreased expression } \\
\text { of pro-inflammatory } \\
\text { cytokines IL-1 } \beta, \text { IL-6, } \\
\text { TNF- a and iNOS } \\
\text { Increased cerebral } \\
\text { neurotrophin levels } \\
\text { and increased } \\
\text { hippocampal } \\
\text { synaptic density }\end{array}$ & $\begin{array}{l}5 \text { weeks } \\
\text { post- operation } \\
\text { Donor cells in the } \\
\text { dentate gyrus } \\
\text { polymorphic layer } \\
70 \% \text { neuron, 20\% } \\
\text { astrocyte phenotypic } \\
\text { differentiation } \\
\text { Improved spatial } \\
\text { memory (Morris } \\
\text { water maze) } \\
\text { Increased } \\
\text { endogenous } \\
\text { neurogenesis in the } \\
\text { dentate gyrus } \\
\text { Reduced cerebral A } \\
\text { levels }\end{array}$ & $\begin{array}{l}6 \text { weeks } \\
\text { post-operation } \\
\text { Donor cells in the } \\
\text { CA1 hippocampal } \\
\text { subregion } \\
36.6 \% \text { and } 41.1 \% \text { cell } \\
\text { survival in } 3 \times \mathrm{Tg}^{-A D} \\
\text { and CaM/Tet-DT } \\
\text { respectively } \\
\text { Improved spatial } \\
\text { memory (Morris } \\
\text { water maze, } \\
\text { context- and } \\
\text { place-dependent } \\
\text { NOR task) } \\
\text { Majority of donor } \\
\text { cells expressed NSC } \\
\text { phenotype } \\
\text { Increased levels } \\
\text { of synaptic } \\
\text { proteins in the } \\
\text { hippocampus } \\
\text { Soluble, } \\
\text { insoluble and } \\
\text { hyperphosphorylated } \\
\text { tau, } A \beta_{40,} \text { and } A \beta_{42} \\
\text { levels unchanged }\end{array}$ & $\begin{array}{l}41 \text { days } \\
\text { post-operation } \\
\text { (first injection) } \\
\text { Improved spatial } \\
\text { memory (Morris } \\
\text { water maze) } \\
\text { Reduced } \\
\text { phosphorylated tau, } \\
\text { A } \beta \text { plaques, vascular } \\
\text { A } \beta_{40} \text {, and BACE-1 } \\
\text { expression in the } \\
\text { cortex and } \\
\text { hippocampus } \\
\text { Increased levels of } \\
\text { activated microglia } \\
\text { in the cortex and } \\
\text { hippocampus } \\
\text { Reduced levels of } \\
\text { pro-inflammatory } \\
\text { cytokines IL-1 } \beta \text { and } \\
\text { TNF-a, and increased } \\
\text { anti-inflammatory } \\
\text { cytokine IL-4 }\end{array}$ & $\begin{array}{l}2 \text { weeks } \\
\text { post-operation } \\
\text { Limited donor cells } \\
\text { in the hippocampus, } \\
\text { and no neural } \\
\text { differentiation } \\
\text { Improved spatial } \\
\text { memory (Morris } \\
\text { water maze) } \\
\text { Reduced levels of } \\
\text { cerebral APP and } \\
\text { BACE1, and reduced } \\
\beta \text { - and } \text {-secretase } \\
\text { activity } \\
\text { Reduced levels of } \\
\text { activated astrocytes } \\
\text { and microglia } \\
\text { Attenuation A } \beta_{1-42} \\
\text { induced } \\
\text { hippocampal } \\
\text { apoptosis, and } \\
\text { impaired } \\
\text { endogenous } \\
\text { neuronal } \\
\text { differentiation } \\
\text { Reduced expression } \\
\text { of inflammatory } \\
\text { proteins iNOS and } \\
\text { COX-2, and an array } \\
\text { of pro-inflammatory } \\
\text { cytokines }\end{array}$ \\
\hline $\begin{array}{l}\text { Therapeutic } \\
\text { mechanism }\end{array}$ & $\begin{array}{l}\text { Modulation of } \\
\text { inflammation }\end{array}$ & $\begin{array}{l}\text { Modulation of } \\
\text { inflammation and } \\
\text { microglia immune } \\
\text { response, and } \\
\text { protection from } A \beta \\
\text { neurotoxicity }\end{array}$ & $\begin{array}{l}\text { Neurotrophic } \\
\text { support of } \\
\text { endogenous } \\
\text { neurogenesis and } \\
\text { synaptic connectivity }\end{array}$ & $\begin{array}{l}\text { Neurotrophic } \\
\text { support of } \\
\text { endogenous } \\
\text { neurogenesis and } \\
\text { synaptic connectivity }\end{array}$ & $\begin{array}{l}\text { Modulation of } \\
\text { inflammation and } \\
\text { microglia, and } \\
\text { anti-amyloidogenic }\end{array}$ & $\begin{array}{l}\text { Neurotrophic } \\
\text { support of } \\
\text { endogenous } \\
\text { neurogenesis, } \\
\text { modulation of } \\
\text { inflammation and } \\
\text { microglia immune } \\
\text { response, and } \\
\text { anti-amyloidogenic }\end{array}$ \\
\hline
\end{tabular}

$A \beta$ amyloid beta, $A D$ Alzheimer's disease, $A-M S C$ adipose-derived mesenchymal stem cell, $B M-M S C$ bone marrow-derived mesenchymal stem cell, $C O X$ cyclooxygenase, GABA gamma-aminobutyric acid, $H$-H Henderson-Hasselbalch, IL interleukin, iNOS inducible nitric oxide synthase, iPSC induced pluripotent stem cell, Ngn neurogenin, NOR novel object recognition, NSC neural stem cell, PBS phosphate-buffered saline, PD-MSC placenta-derived mesenchymal stem cell, PGE prostaglandin, PTGER prostaglandin E receptor, TNF tumour necrosis factor, U-MSC umbilical cord Warton's jelly-derived mesenchymal stem cell, U-MSC-NC neuronal-like cell differentiated from umbilical cord Warton's jelly-derived mesenchymal stem cell, UCB-MSC umbilical cord blood-derived mesenchymal stem cell 
Table 1 AD rodent model stem cell transplantation studies in the last 5 years (Continued)

\begin{tabular}{|c|c|c|c|c|c|}
\hline Study & [36] & [37] & [38] & [39] & [45] \\
\hline Cell type & $\begin{array}{l}\text { Human U-MSCs } \\
\text { Human U-MSC-NCS }\end{array}$ & Human A-MSCs & Murine BM-MSCs & Human BM-MSCs & $\begin{array}{l}\text { Human iPSC-derived } \\
\text { neuronal precursors }\end{array}$ \\
\hline Model & $\begin{array}{l}\text { B6C3-Tg } \\
\text { (APPswe/ } \\
\text { PSEN1dE9) } \\
\text { transgenic mice }\end{array}$ & $\begin{array}{l}\text { Tg2576 } \\
\text { (APPswe) transgenic } \\
\text { mice } \\
3 \times T g-A D \\
\text { transgenic mice }\end{array}$ & $\begin{array}{l}\text { APP/PS1 transgenic } \\
\text { mice }\end{array}$ & $\begin{array}{l}\mathrm{A} \beta_{1-42} \\
\text { cerebro-ventricular } \\
\text { infused mice }\end{array}$ & $\begin{array}{l}\text { PDAPP transgenic } \\
\text { mice }\end{array}$ \\
\hline $\begin{array}{l}\text { Delivery } \\
\text { route }\end{array}$ & $\begin{array}{l}\text { Bilateral intra- } \\
\text { hippocampal } \\
\text { stereotactic injection } \\
5 \times 10^{4} \text { cells } \\
\text { Sham: PBS vehicle }\end{array}$ & $\begin{array}{l}\text { Intravenous injection } \\
2 \times 10^{6} \text { cells } \\
\text { Sham: PBS vehicle }\end{array}$ & $\begin{array}{l}\text { Intravenous injection } \\
1 \times 10^{6} \text { cells Sham: } \\
\mathrm{NaCl} \text { solution vehicle }\end{array}$ & $\begin{array}{l}\text { Intravenous injection } \\
1 \times 10^{6} \text { cells Sham: } \\
\text { PBS vehicle }\end{array}$ & $\begin{array}{l}\text { Bilateral intra- } \\
\text { hippocampal } \\
\text { stereotactic injection } \\
2 \times 10^{5} \text { cells Sham: } \\
\text { PBS vehicle }\end{array}$ \\
\hline Findings & $\begin{array}{l}4 \text { weeks } \\
\text { post-operation } \\
\text { No donor cells } \\
\text { present at } 4 \text { weeks } \\
\text { post-surgery } \\
\text { Improved spatial } \\
\text { memory (Morris } \\
\text { water maze) in the } \\
\text { U-MSC-NC group } \\
\text { Increased } \\
\text { hippocampal levels } \\
\text { of synapsin I in the } \\
\text { U-MSC-NC group } \\
\text { Decreased } \\
\text { hippocampal AB } \\
\text { deposition, } \\
\text { decreased soluble } \\
\text { A } 40 \text { and A } \beta_{42} \text { levels, } \\
\text { and increased } \\
\text { AB-degrading } \\
\text { enzymes in the } \\
\text { U-MSC-NC group } \\
\text { Increased number of } \\
\text { M2 activated } \\
\text { microglia in the } \\
\text { U-MSC-NC group } \\
\text { Reduced pro- } \\
\text { inflammatory } \\
\text { cytokines (IL-1 } 1 \beta \text { and } \\
\text { TNF-a), and increased } \\
\text { anti-inflammatory } \\
\text { cytokine IL-4 in the } \\
\text { U-MSC-NC group }\end{array}$ & $\begin{array}{l}6 \text { weeks } \\
\text { post-operation } \\
\text { (Tg2576 mice) } \\
\text { Improved spatial } \\
\text { memory (Morris } \\
\text { water maze) } \\
1 \text { and } 12 \text { weeks } \\
\text { post-operation } \\
\text { ( } 3 \times \text { Tg-AD mice) } \\
\text { Donor cells in the } \\
\text { spleen, lung, liver, } \\
\text { but not brain } \\
\text { Reduced number } \\
\text { and size of A } \\
\text { plaques } \\
\text { Increased density of } \\
\text { activated microglia } \\
\text { in the hippocampus } \\
\text { by week } 1 \text {, lower } \\
\text { density than in sham } \\
\text { animals by week } 12 \\
\text { Increased } \\
\text { phagocytotic } \\
\text { microglia } \\
\text { Reduced } \\
\text { proinflammatory } \\
\text { cytokines IL-1 and } \\
\text { TNF-a at week } 1 \\
\text { Increased anti- } \\
\text { inflammatory } \\
\text { cytokines IL-10 and } \\
\text { TNF- } \beta \text { at week } 12 \\
\text { Increased levels of } \\
\text { A } \beta \text {-degrading } \\
\text { enzymes }\end{array}$ & 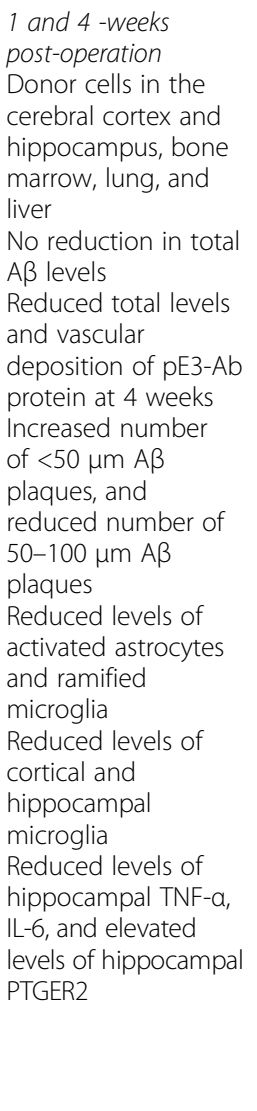 & $\begin{array}{l}\text { 1, 2, and } 4 \text { weeks } \\
\text { post-operation } \\
\text { Donor cell neuronal } \\
\text { differentiation in the } \\
\text { entorhinal cortex } \\
\text { and hippocampus } \\
\text { Improved working } \\
\text { memory } \\
\text { performance (Radial } \\
\text { Arm Maze) } \\
\text { Attenuation of } \\
\text { impaired } \\
\text { neurogenesis and } \\
\text { neuronal } \\
\text { differentiation in the } \\
\text { hippocampus at } \\
\text { 2- and 4-week } \\
\text { time points } \\
\text { Increased } \\
\text { hippocampal } \\
\text { expression of neural } \\
\text { specification proteins } \\
\beta \text {-catenin and Ngn1 }\end{array}$ & $\begin{array}{l}2 \text { weeks } \\
\text { post-operation } \\
\text { Improved spatial } \\
\text { memory (Morris } \\
\text { water maze) } \\
45 \text { days } \\
\text { post-operation } \\
\text { Improved spatial } \\
\text { memory (Morris } \\
\text { water maze) } \\
\text { Donor cell survival } \\
\text { and neuronal } \\
\text { differentiation in the } \\
\text { hippocampus } \\
\text { Donor cells } \\
\text { expression of } \\
\text { cholinergic and } \\
\text { GABAergic neuronal } \\
\text { markers }\end{array}$ \\
\hline $\begin{array}{l}\text { Therapeutic } \\
\text { mechanism }\end{array}$ & $\begin{array}{l}\text { Modulation of } \\
\text { inflammation and } \\
\text { microglia immune } \\
\text { response }\end{array}$ & $\begin{array}{l}\text { Modulation of } \\
\text { inflammation and } \\
\text { microglia immune } \\
\text { response }\end{array}$ & $\begin{array}{l}\text { Modulation of } \\
\text { microglia immune } \\
\text { response }\end{array}$ & $\begin{array}{l}\text { Neurotrophic } \\
\text { support of } \\
\text { endogenous } \\
\text { neurogenesis } \\
\text { and protection from } \\
A \beta \text { neurotoxicity }\end{array}$ & $\begin{array}{l}\text { Regeneration of } \\
\text { depleted neural } \\
\text { networks }\end{array}$ \\
\hline
\end{tabular}

\section{ESCs}

While some ESC transplantation studies have shown a capacity to restore cognitive function in rodent models of brain injury [11], their clinical translation has been limited. This is in part due to their pluripotent nature, as transplantation of undifferentiated ESCs presents an inherent risk of uncontrolled cell growth and tumour formation [12]. In vitro pre-differentiation of ESCs into NSCs circumvents some of this risk, generating predominantly cholinergic neurons and inducing improvements in spatial memory performance after transplantation into an AD rodent model [13]. More recently, one study reported the stable generation of cholinergic neuronal populations from human ESCs which, following transplantation, were able to functionally integrate into hippocampal neuronal circuitry [14]. In 2013, another study reported the conversion of ESCs into medial ganglionic eminence-like progenitor cells-a transient 
stem cell type present in the developing brain. Following transplantation into a murine brain injury model, these cells were capable of maturing into both GABAergic and cholinergic neuronal subtypes and synaptically integrating with host neuronal circuits, leading to improvements in impaired spatial memory and learning [15]. Despite ongoing preclinical studies, there are inherent ethical and immunogenic limitations to using allogeneic donor cells that significantly hamper the clinical translation of ESC-based therapies.

\section{NSCS}

The paracrine effect of NSCs has been shown to have significant therapeutic potential. Transplanting growth factor-secreting NSCs increased neurogenesis and cognitive function in a rodent $\mathrm{AD}$ model [16] and aged primate brain [17], while transplantation of choline acetyltransferaseoverexpressing human NSCs into a cholinergic neurotoxic rodent model resulted in a reversal of spatial memory and learning deficits [18]. Other recent AD rodent model studies have reported that NSC transplantation decreased neuroinflammation [19], attenuation of tau and $\mathrm{A} \beta \mathrm{AD}$ neuropathology [20], promotion of neurogenesis and synaptogenesis [21, 22], and reversal of cognitive deficits $[19,21,22]$. While the therapeutic mechanisms behind these changes are not yet fully understood, they are likely mediated by both the paracrine release of neuroprotective or immune modulatory factors [16] and by direct neuronal differentiation $[13,23]$, although the widespread generation of non-neuronal glial cell types from transplanted NSCs remains a major limiting factor for neuroreplacement strategies [23].

\section{MSCS}

Due to their accessibility, relative ease of handling, and the broad range of cell types that they are able to generate, MSCs are now among the most frequently studied stem cell type. In aged rodent models, transplanted MSCs were shown to undergo differentiation into neural cell types, increasing local concentrations of acetylcholine neurotransmitter, BDNF, and NGF, and improving locomotor and cognitive function [24]. However, to date there has been little evidence for the functional or synaptic maturation of MSC-derived neurons in vivo. Moreover, genuine neuroreplacement by MSCs remains limited by low rates of neuronal differentiation and a propensity for glial cell formation in vivo [25]. Potentially of greater therapeutic significance are the reported neuroprotective paracrine effects of MSCs, with the introduction of MSC-secreted factors able to stimulate proliferation, neuronal differentiation, and survival in endogenous neurogenic niches $[26,27]$ and in cellular models of AD [28]. Similarly, in rodent AD models, MSC transplantation has been reported to inhibit $\mathrm{A} \beta$ - and tau- related cell death $[28,29]$, reduce $A \beta$ deposits and plaque formation [30-33], stimulate neurogenesis, synaptogenesis, and neuronal differentiation [28, 31, 34], and rescue spatial learning and memory deficits [29-32]. Some studies suggest a further anti-inflammatory and immune modulatory paracrine effect for transplanted MSCs, including upregulated neuroprotective cytokines such as IL-10, and reduced levels of pro-inflammatory cytokines TNF- $\alpha$ and IL-1 $\beta$ [29-32]. Intravenously administered MSCs are also capable of crossing the blood-brain barrier and effectively migrating to regions of neural injury, without inducing a tumourigenic or immune response [35]. This minimally invasive approach has significant advantages over traditional intracranial injection when considering human clinical translation, although reports of MSCs infiltrating into multiple organs remains a concern for this delivery system $[34,35]$.

\section{iPSCs}

iPSC-derived neurons are structurally and functionally mature, and capable of forming electrophysiologically active synaptic networks [36]. Using additional transcription factors during the induction process, it has also been possible to direct differentiation into specific neuronal subtypes, such as dopaminergic neurons [37]. As iPSCs are a relatively new technology, preclinical animal model transplantation studies are few. One study in an ischaemic stroke rodent model demonstrated that human iPSC-derived NSCs were able to improve neurological function and reduce pro-inflammatory factors through a neurotrophinassociated bystander effect [38]. In another recent study, following intra-hippocampal transplantation into a transgenic $\mathrm{AD}$ mouse model, human iPSC-derived cholinergic neuronal precursors survived, differentiated into phenotypically mature cholinergic neurons, and reversed spatial memory impairment [39].

iPSC technology allows for the production of autologous pluripotent stem cells, thereby avoiding both the ethical limitations and immune rejection issues of non-patientspecific sources. Long-term survival and efficacy of autologous iPSC-derived dopaminergic neuronal transplantation has been demonstrated in a simian Parkinson's disease model, with improved motor activity and function, and extensive cell survival and engraftment at 2-years postoperation [40]. However, autologous iPSCs may be of limited use for neuroreplacement as neurons generated from $\mathrm{AD}$ patients display phenotypic neuropathology, including abnormal A $\beta$ levels, elevated tau phosphorylation, reduced neurite length, and altered electrocompetency [41-43]. Alternatively, using iPSC-derived neurons to recapitulate $\mathrm{AD}$ pathology in vitro has significant applications in the study of pathogenesis and screening for potential therapeutic drugs. As such, they are now the subject of extensive study in vitro, as reviewed elsewhere [44]. 


\section{Stem cell trials in humans}

Inconsistencies in preclinical studies have prevented several potential stem cell therapies from transitioning to human clinical trials. By contrast, evidence for the safety and efficacy of MSC-based therapies in animal models, combined with ease of handling and isolation, has supported the approval of several human clinical trials.

A recently completed open-label phase I clinical trial evaluated the safety and the tolerability of intracranially injected allogeneic human umbilical cord blood-derived MSCs (Trial identifier: NCT01297218, NCT01696591) [45]. Nine patients, defined by the National Institute of Neurological and Communicative Disorders and StrokeAlzheimer's Disease and Related Disorders Association criteria as having probable AD, were enrolled in the trial. Mini-Mental State Examination scoring between 10 and 24. (mild-moderate AD dementia), and Pittsburgh compound $\mathrm{B}$ positron emission tomography confirmation of A $\beta$ pathology were used as inclusion criteria. Trial participants were then divided into low-dose $\left(3 \times 10^{6}\right.$ cells; $n=3)$ and high-dose $\left(6 \times 10^{6}\right.$ cells; $\left.n=6\right)$ groups, and received bilateral stereotactic injection of human umbilical cord blood-derived MSCs into the hippocampus and precuneus. At 3 months and 24 months post-treatment time points, no patient showed any serious adverse event resulting from either the surgical procedure or transplantation of MSCs. However, MSC transplantation did not slow cognitive decline over the 24 months of follow-up, as measured by the Alzheimer's Disease Assessment Scalecognitive subscale. Furthermore, no changes to AD pathology were observed. The neuroprotective effect of MSCs, frequently reported in AD animal models [30-32], was therefore not evident. The authors suggest this may be due in part to a reliance on neuroimaging rather than more sensitive post-mortem biochemical analyses used in animal studies.

Details of ongoing trials are summarised in Table 2. While many of these employ an intravenous infusion administration route, one trial (Trial identifier: NCT02054208) will assess the safety and efficacy of intraventricular MSC injection via an Ommaya reservoir system. Umbilical cord blood-derived MSCs remain a common cell choice, although key differences exist with regards to cell number, dose number, and dose schedule. Two separate trials, both currently undergoing recruitment, will utilise alternative MSC sources. One trial (Trial identifier: NCT02912169) will assess the safety and efficacy of autologous adipose-derived stromal vascular fraction cells acquired from patient liposuction. Another study (Trial identifier: NCT02833792) will utilise ischaemia-tolerant allogeneic human bone marrowderived MSCs. Grown under hypoxic conditions to more closely resemble the physiological environment of the
CNS, these MSCs express higher levels of angiogenic growth factors, including VEGF and angiopoietin, and show enhanced migratory activity [46].

\section{Future directions}

Preclinical studies suggest that stem cells have potential for the treatment of $\mathrm{AD}$; however, this area is notable for poor translation between animal studies and human trials. Indeed, researchers have effectively treated $\mathrm{AD}$ in transgenic mouse models in more than 50 different ways [47]. Transgenic models demonstrate little, if any, predictive utility. Their outcomes are frequently model-dependent and, disappointingly, each approach has failed in human clinical trials. Transgenic models are largely based on familial ADrelated hypotheses in a genetically homogeneous population, while the vast majority of human AD occurs sporadically amongst a distinctly heterogeneous population. Moreover, they do not recapitulate the extensive neuronal and synaptic loss that is central to AD. Clearly, rodent models and their aetiological hypotheses are inadequate for predicting human clinical outcomes. AD cell therapies will therefore need to demonstrate success in higher-order animals that more faithfully mimic the clinical and neurodegenerative features of the human condition.

Several key questions also need to be addressed, including long-term safety, optimum cell source and the delivery system, understanding donor cell response to the pathogenic AD environment, and clarifying the mechanisms of action. Many of the studies discussed here utilised inherently heterotopic stem cells. While this is a clinically relevant strategy due to the inaccessible nature of the adult NSC niche, this too requires careful consideration. Human and rodent studies have reported tumour formation resulting from autologous haematopoietic stem cell [48], allogeneic fetal NSC [49], and genetically engineered MSC [50] transplantation. While neuroreplacement therapies may not be able to fully compensate for widespread and progressive neuronal loss, they may serve to temporarily enhance existing depleted circuits, which is sufficient to improve cognition function, restore daily function, and improve quality of life. Upon diagnosis, lifespan for individuals with AD dementia is $4-5$ years, and so if a neuroreplacement therapy could rescue and protect brain function for that timespan it is commensurate to a functional cure. Alternatively, due to the complex nature of AD pathophysiology, a multimodal approach may be required, incorporating pharmacological targeting of pathology, stimulation of endogenous neurogenesis and synaptogenesis, as well as exogenous neuroreplacement. 


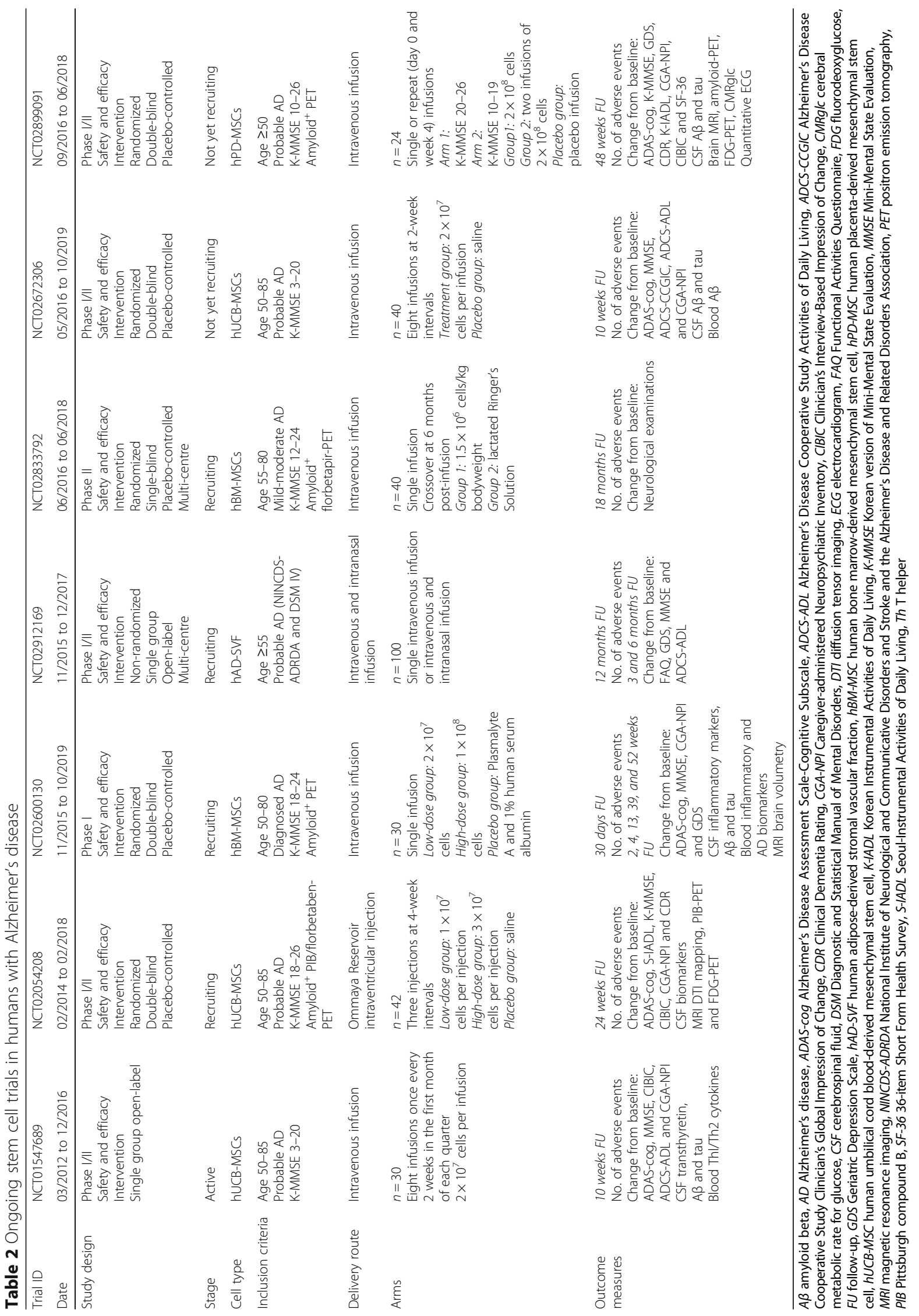




\section{Conclusion}

Stem cell therapy for AD carries enormous promise but remains under development. There is now substantive preclinical literature that demonstrates proof-of-concept, with new studies continuing to reveal potential therapeutic mechanisms. MSC-based therapeutics have been the most consistent and have reached human clinical trials. To date, one such trial was negative but there are many others underway. Researchers must, however, be aware of the perilous gulf that lies between rodents and humans. Not only do we need to better understand the cells and the brains they intend to repair, but also employ translational models that begin to bridge this gap.

\begin{abstract}
Abbreviations
AB: Amyloid beta; AD: Alzheimer's disease; ApoE4: Apolipoprotein-E4; BDNF: Brain-derived neurotrophic factor; CA: Cornu Ammonis; CNS: Central nervous system; ESC: Embryonic stem cell; GABA: Gamma-aminobutyric acid; IGF-1: Insulin growth factor-1; IL: Interleukin; iPSC: Induced pluripotent stem cell; MSC: Mesenchymal stem cell; NGF: Nerve growth factor; NO: Nitric oxide; NSC: Neural stem cell; TNF: Tumour necrosis factor; UCB-MSC: Umbilical cord blood-derived mesenchymal stem cell; VEGF: Vascular endothelial growth factor
\end{abstract}

\section{Acknowledgements}

Not applicable.

\section{Funding}

Not applicable.

\section{Availability of data and materials}

The human clinical trials data included in this review are available at https://clinicaltrials.gov/.

\section{Authors' contributions}

TD and MV were involved in the writing, revision, and final approval of the manuscript.

\section{Authors' information}

Not applicable.

\section{Competing interests}

The authors declare that they have no competing interests.

\section{Consent for publication}

All figures and tables in this manuscript are original and all authors approved the submission.

\section{Ethical approval and consent to participate}

Not applicable.

\section{Publisher's Note}

Springer Nature remains neutral with regard to jurisdictional claims in published maps and institutional affiliations.

Published online: 12 May 2017

\section{References}

1. Alzheimers Association. 2015 Alzheimer's disease facts and figures. Alzheimers Dement. 2015;11:332.

2. Salloway S, Sperling R, Fox NC, Blennow K, Klunk W, Raskind M, Sabbagh M, Honig LS, Porsteinsson AP, Ferris S. Two phase 3 trials of bapineuzumab in mild-to-moderate Alzheimer's disease. N Engl J Med. 2014;370:322-33.

3. Doody RS, Raman R, Farlow M, Iwatsubo T, Vellas B, Joffe S, Kieburtz K, He F, Sun $X$, Thomas RG. A phase 3 trial of semagacestat for treatment of Alzheimer's disease. N Engl J Med. 2013;369:341-50.
4. Walker D, Lue LF. Investigations with cultured human microglia on pathogenic mechanisms of Alzheimer's disease and other neurodegenerative diseases. J Neurosci Res. 2005;81:412-25.

5. Delbeuck X, Van der Linden M, Collette F. Alzheimer's disease as a disconnection syndrome? Neuropsychol Rev. 2003;13:79-92.

6. Hass R, Kasper C, Böhm S, Jacobs R. Different populations and sources of human mesenchymal stem cells (MSC): a comparison of adult and neonatal tissue-derived MSC. Cell Commun Signal. 2011;9:1.

7. Takahashi K, Yamanaka S. Induction of pluripotent stem cells from mouse embryonic and adult fibroblast cultures by defined factors. Cell. 2006;126:663-76.

8. Jin K, Zhu Y, Sun Y, Mao XO, Xie L, Greenberg DA. Vascular endothelial growth factor (VEGF) stimulates neurogenesis in vitro and in vivo. Proc Natl Acad Sci. 2002;99:11946-50.

9. Lopez-Toledano MA, Shelanski ML. Increased neurogenesis in young transgenic mice overexpressing human APP. J Alzheimers Dis. 2007;12:229-40.

10. Donovan MH, Yazdani U, Norris RD, Games D, German DC, Eisch AJ. Decreased adult hippocampal neurogenesis in the PDAPP mouse model of Alzheimer's disease. J Comp Neurol. 2006;495:70-83.

11. Acharya MM, Christie L-A, Lan ML, Donovan PJ, Cotman CW, Fike JR, Limoli CL. Rescue of radiation-induced cognitive impairment through cranial transplantation of human embryonic stem cells. Proc Natl Acad Sci. 2009;106:19150-5.

12. Fong $\mathrm{CY}$, Gauthaman $\mathrm{K}$, Bongso A. Teratomas from pluripotent stem cells: a clinical hurdle. J Cell Biochem. 2010;111:769-81.

13. Moghadam FH, Alaie H, Karbalaie K, Tanhaei S, Esfahani MHN, Baharvand H. Transplantation of primed or unprimed mouse embryonic stem cell-derived neural precursor cells improves cognitive function in Alzheimerian rats. Differentiation. 2009:78:59-68.

14. Bissonnette CJ, Lyass L, Bhattacharyya BJ, Belmadani A, Miller RJ, Kessler JA. The controlled generation of functional basal forebrain cholinergic neurons from human embryonic stem cells. Stem Cells. 2011;29:802-11.

15. Liu Y, Weick JP, Liu H, Krencik R, Zhang X, Ma L, Zhou G-m, Ayala M, Zhang S-C. Medial ganglionic eminence-like cells derived from human embryonic stem cells correct learning and memory deficits. Nat Biotechnol. 2013;31:440-7

16. Blurton-Jones M, Kitazawa M, Martinez-Coria H, Castello NA, Müller F-J, Loring JF, Yamasaki TR, Poon WW, Green KN, LaFerla FM. Neural stem cells improve cognition via BDNF in a transgenic model of Alzheimer disease. Proc Natl Acad Sci. 2009;106:13594-9.

17. Kordower JH, Winn SR, Liu Y-T, Mufson EJ, Sladek JR, Hammang JP, Baetge EE, Emerich DF. The aged monkey basal forebrain: rescue and sprouting of axotomized basal forebrain neurons after grafts of encapsulated cells secreting human nerve growth factor. Proc Natl Acad Sci. 1994;91:10898-902.

18. Park D, Yang Y-H, Bae DK, Lee SH, Yang G, Kyung J, Kim D, Choi E-K, Lee SW, Kim GH. Improvement of cognitive function and physical activity of aging mice by human neural stem cells over-expressing choline acetyltransferase. Neurobiol Aging. 2013;34:2639-46.

19. Zhang Q, Wu Hh, Wang Y, Gu Gj, Zhang W, Xia R. Neural stem cell transplantation decreases neuroinflammation in a transgenic mouse model of Alzheimer's disease. J Neurochem. 2015:136:815-825.

20. Lee I-S, Jung K, Kim I-S, Lee H, Kim M, Yun S, Hwang K, Shin JE, Park KI. Human neural stem cells alleviate Alzheimer-like pathology in a mouse model. Mol Neurodegener. 2015;10:1.

21. Lilja AM, Malmsten L, Röjdner J, Voytenko L, Verkhratsky A, Ögren SO, Nordberg A, Marutle A. Neural stem cell transplant-induced effect on neurogenesis and cognition in Alzheimer Tg2576 mice is inhibited by concomitant treatment with amyloid-lowering or cholinergic 7 nicotinic receptor drugs. Neural Plast. 2015;2015:370432.

22. Ager RR, Davis $J$, Agazaryan A, Benavente F, Poon WW, LaFerla FM, Blurton-Jones M. Human neural stem cells improve cognition and promote synaptic growth in two complementary transgenic models of Alzheimer's disease and neuronal loss. Hippocampus. 2015;25:813-26.

23. Xuan A, Luo M, Ji W, Long D. Effects of engrafted neural stem cells in Alzheimer's disease rats. Neurosci Lett. 2009;450:167-71.

24. Park D, Yang G, Bae DK, Lee SH, Yang YH, Kyung J, Kim D, Choi EK, Choi KC, Kim SU. Human adipose tissue-derived mesenchymal stem cells improve cognitive function and physical activity in ageing mice. J Neurosci Res. 2013;91:660-70 
25. Lee J, Kuroda S, Shichinohe H, Ikeda J, Seki T, Hida K, Tada M, Sawada K, Iwasaki Y. Migration and differentiation of nuclear fluorescence-labeled bone marrow stromal cells after transplantation into cerebral infarct and spinal cord injury in mice. Neuropathology. 2003;23:169-80.

26. Munoz JR, Stoutenger BR, Robinson AP, Spees JL, Prockop DJ. Human stem/ progenitor cells from bone marrow promote neurogenesis of endogenous neural stem cells in the hippocampus of mice. Proc Natl Acad Sci U S A. 2005;102:18171-6.

27. Teixeira FG, Carvalho MM, Neves-Carvalho A, Panchalingam KM, Behie LA, Pinto L, Sousa N, Salgado AJ. Secretome of mesenchymal progenitors from the umbilical cord acts as modulator of neural/glial proliferation and differentiation. Stem Cell Rev Rep. 2015;11:288-97.

28. Zilka N, Zilkova M, Kazmerova Z, Sarissky M, Cigankova V, Novak M. Mesenchymal stem cells rescue the Alzheimer's disease cell model from cell death induced by misfolded truncated tau. Neuroscience. 2011;193:330-7.

29. Lee HJ, Lee JK, Lee H, Carter JE, Chang JW, Oh W, Yang YS, Suh J-G, Lee B-H, Jin HK. Human umbilical cord blood-derived mesenchymal stem cells improve neuropathology and cognitive impairment in an Alzheimer's disease mouse model through modulation of neuroinflammation. Neurobiol Aging. 2012;33:588-602.

30. Yun H, Kim H, Park K, Shin J, Kang A, II Lee K, Song S, Kim Y, Han S, Chung $\mathrm{H}$. Placenta-derived mesenchymal stem cells improve memory dysfunction in an Aß1-42-infused mouse model of Alzheimer's disease. Cell Death Dis. 2013;4, e958.

31. Yang $H$, Xie ZH, Wei LF, Yang HN, Yang SN, Zhu ZY, Wang P, Zhao CP, Bi JZ. Human umbilical cord mesenchymal stem cell-derived neuron-like cells rescue memory deficits and reduce amyloid-beta deposition in an AßPP/PS1 transgenic mouse model. Stem Cell Res Ther. 2013;4:1.

32. Kim K-S, Kim HS, Park J-M, Kim HW, M-k P, Lee H-S, Lim DS, Lee TH, Chopp M, Moon J. Long-term immunomodulatory effect of amniotic stem cells in an Alzheimer's disease model. Neurobiol Aging. 2013;34:2408-20.

33. Naaldijk Y, Jaeger C, Fabian C, Leovsky C, Blüher A, Rudolph L, Hinze A, Stolzing A. Effect of systemic transplantation of bone marrow-derived mesenchymal stem cells on neuropathology markers in APP/PS1 Alzheimer mice. Neuropathol Appl Neurobiol. 2016.

34. Oh SH, Kim HN, Park H-J, Shin JY, Lee PH. Mesenchymal stem cells increase hippocampal neurogenesis and neuronal differentiation by enhancing the Wnt signaling pathway in an Alzheimer's disease model. Cell Transplant. 2015;24:1097-109.

35. Ra JC, Shin IS, Kim SH, Kang SK, Kang BC, Lee HY, Kim YJ, Jo JY, Yoon EJ, Choi HJ. Safety of intravenous infusion of human adipose tissue-derived mesenchymal stem cells in animals and humans. Stem Cells Dev. 2011;20:1297-308.

36. Pang ZP, Yang N, Vierbuchen $T$, Ostermeier A, Fuentes DR, Yang TQ, Citri A, Sebastiano V, Marro S, Südhof TC. Induction of human neuronal cells by defined transcription factors. Nature. 2011;476:220-3.

37. Liu X, Li F, Stubblefield EA, Blanchard B, Richards TL, Larson GA, He Y, Huang Q, Tan A-C, Zhang D. Direct reprogramming of human fibroblasts into dopaminergic neuron-like cells. Cell Res. 2012;22:321-32.

38. Eckert A, Huang L, Gonzalez R, Kim H-S, Hamblin MH, Lee J-P. Bystander effect fuels human induced pluripotent stem cell-derived neural stem cells to quickly attenuate early stage neurological deficits after stroke. Stem Cells Transl Med. 2015;4:841-51.

39. Fujiwara N, Shimizu J, Takai K, Arimitsu N, Saito A, Kono T, Umehara T, Ueda Y, Wakisaka S, Suzuki T. Restoration of spatial memory dysfunction of human APP transgenic mice by transplantation of neuronal precursors derived from human iPS cells. Neurosci Lett. 2013:557:129-34.

40. Hallett PJ, Deleidi M, Astradsson A, Smith GA, Cooper O, Osborn TM, Sundberg M, Moore MA, Perez-Torres E, Brownell A-L. Successful function of autologous iPSC-derived dopamine neurons following transplantation in a non-human primate model of Parkinson's disease. Cell Stem Cell. 2015;16:269-74

41. Balez R, Steiner N, Engel M, Muñoz SS, Lum JS, Wu Y, Wang D, Vallotton P, Sachdev P, O'Connor M. Neuroprotective effects of apigenin against inflammation, neuronal excitability and apoptosis in an induced pluripotent stem cell model of Alzheimer's disease. Sci Report. 2016;6:31450.

42. Hossini AM, Megges M, Prigione A, Lichtner B, Toliat MR, Wruck W, Schröter F, Nuernberg P, Kroll H, Makrantonaki E. Induced pluripotent stem cell-derived neuronal cells from a sporadic Alzheimer's disease donor as a model for investigating AD-associated gene regulatory networks. BMC Genomics. 2015;16:1.
43. Muratore CR, Rice HC, Srikanth P, Callahan DG, Shin T, Benjamin LN, Walsh DM, Selkoe DJ, Young-Pearse TL. The familial Alzheimer's disease APPV717| mutation alters APP processing and Tau expression in iPSC-derived neurons. Hum Mol Genet. 2014;23:3523-36.

44. Truong A, Si E, Duncan T, Valenzuela M. Modeling neurodegenerative disorders in adult somatic cells: a critical review. Front Biol. 2016;11:232-45.

45. Kim HJ, Seo SW, Chang JW, Lee JI, Kim CH, Chin J, Choi SJ, Kwon H, Yun HJ, Lee JM. Stereotactic brain injection of human umbilical cord blood mesenchymal stem cells in patients with Alzheimer's disease dementia: a phase 1 clinical trial. Alzheimers Dement. 2015;1:95-102.

46. Vertelov G, Kharazi L, Muralidhar M, Sanati G, Tankovich T, Kharazi A. High targeted migration of human mesenchymal stem cells grown in hypoxia is associated with enhanced activation of RhoA. Stem Cell Res Ther. 2013;4:1.

47. Cummings JL, Morstorf T, Zhong K. Alzheimer's disease drug-development pipeline: few candidates, frequent failures. Alzheimers Res Ther. 2014;6:37-44.

48. Thirabanjasak D, Tantiwongse K, Thorner PS. Angiomyeloproliferative lesions following autologous stem cell therapy. J Am Soc Nephrol. 2010;21:1218-22.

49. Amariglio N, Hirshberg A, Scheithauer BW, Cohen Y, Loewenthal R, Trakhtenbrot L, Paz N, Koren-Michowitz M, Waldman D, Leider-Trejo L. Donor-derived brain tumor following neural stem cell transplantation in an ataxia telangiectasia patient. PLoS Med. 2009;6:e1000029.

50. Fazel SS, Angoulvant D, Butany J, Weisel RD, Li R-K. Mesenchymal stem cells engineered to overexpress stem cell factor improve cardiac function but have malignant potential. J Thorac Cardiovasc Surg. 2008;136:1388-9. 